\section{Potential Economic Impacts from Offshore Wind in the Southeast Region}

Offshore wind is a clean, renewable source of energy and can be an economic driver in the United States. To better understand the employment opportunities and other potential regional economic impacts from offshore wind development, the U.S. Department of Energy (DOE) funded research that focuses on four regions of the country. The studies use multiple scenarios with various local job and domestic manufacturing content assumptions. Each regional study uses the new offshore wind Jobs and Economic Development Impacts (JEDI) model, developed by the National Renewable Energy Laboratory. ${ }^{1}$ This fact sheet summarizes the potential economic impacts identified by the study for the Southeast.

\section{JEDI Models}

The JEDI models are spreadsheet-based tools that estimate the economic impacts of constructing and operating power plants, fuel-production facilities, and other projects at the local level. JEDI results are intended to be estimates, not precise predictions. Based on user-entered project-specific data or default inputs (derived from industry norms), JEDI models estimate the number of jobs and other economic impacts to a local area (in this case, the Southeast) that can reasonably be supported by a new power plant, like an offshore wind facility. The JEDI models estimate gross impacts and are not a measure of project profitability or viability. Jobs, earnings, and regional economic output are distributed across three categories:

- Project Development and Onsite Labor Impacts

- Local Revenue and Supply Chain Impacts

- Induced Impacts.

Economic multipliers contained within the model are derived from Minnesota IMPLAN Group's IMPLAN accounting software and state data files. Jobs are measured and reported as full-time equivalents (FTEs). One FTE is equivalent to one full-time worker who is employed

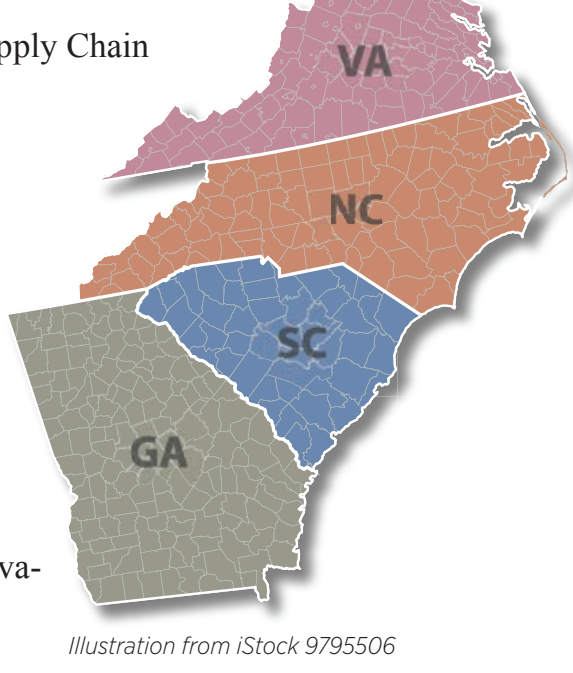

${ }^{1}$ The model can be downloaded free of charge at www.nrel.gov/analysis/jedi.

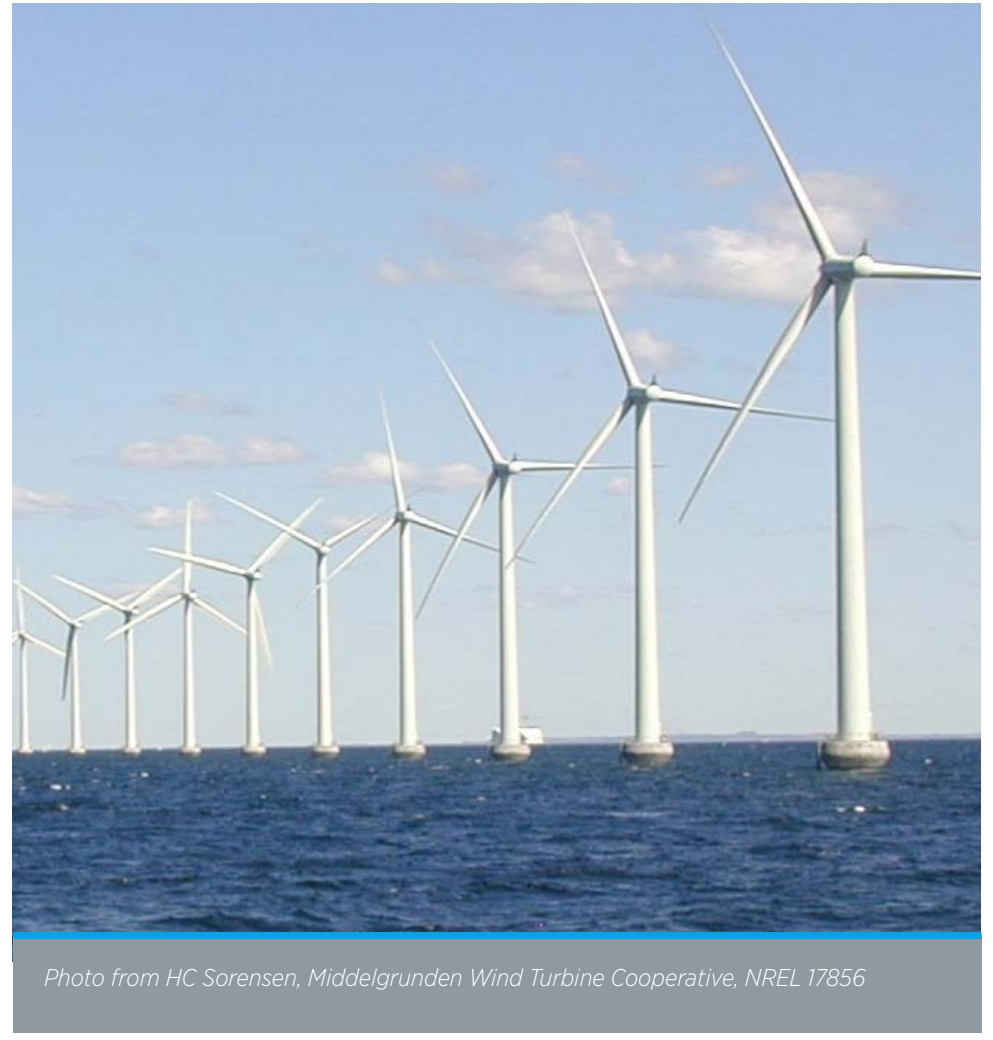

for 1 year - part-time and seasonal workers are a fraction of an FTE. The results of each scenario represent an estimate of the number of cumulative construction jobs that could be supported in the Southeast Region (Figure 1). The wide range of potential jobs illustrates the uncertainty involved in estimating economic impacts over a 10-year span.

\section{The Southeast}

The Southeast Region is defined here as Georgia, South Carolina, North Carolina, and Virginia.

This study considered five offshore wind development scenarios examining different levels of capacity installed, local supply chain investment, and construction/operation costs. Offshore wind installations range from a low of 95 megawatts (MW) by 2020 to a high of almost 9,800 MW by 2030 (Table 1). The low-deployment scenario represents few installations beyond small pilot and test projects while the high-deployment scenario assumes that nearly all forecasted growth in electricity generation capacity in the Southeast would be met with offshore wind. In the medium-deployment scenario, offshore wind installations begin with smaller test projects but grow steadily over time.

Investment would be needed by manufacturers and other important industries in the Southeast Region's offshore wind supply chain before many of the materials needed to construct and operate an offshore wind plant could be purchased in the area. In 2020, the assumed portion of labor, material, and equipment sourced locally ranges from $22 \%$ to $30 \%$; by 2030 , this range is 
$40 \%$ to $81 \%$. Construction costs are also assumed to vary, ranging from $\$ 5,000 /$ kilowatt ( $\mathrm{kW}$ ) to $\$ 5,400 / \mathrm{kW}$ in 2020 to $\$ 3,900 /$ $\mathrm{kW}$ to $\$ 5,000 / \mathrm{kW}$ in 2030 . O\&M costs are assumed to be stable at $\$ 133 / \mathrm{kW}$ regardless of the capacity deployed and local content.

Table 1. Scenarios Modeled (2020 Value / 2030 Value) for Offshore Wind in the Southeast

\begin{tabular}{|c|c|c|c|c|}
\hline \multirow[b]{2}{*}{ Scenario } & \multirow[b]{2}{*}{$\begin{array}{l}\text { Scenario } \\
\text { Detail }\end{array}$} & \multicolumn{3}{|c|}{$2020 / 2030$} \\
\hline & & $\begin{array}{c}\text { Cumulative } \\
\text { Capacity } \\
\text { Installed } \\
\text { (MW) }\end{array}$ & $\begin{array}{l}\text { Supply } \\
\text { Chain } \\
\text { Investment } \\
\text { (Local } \\
\text { Content) }\end{array}$ & $\begin{array}{l}\text { Construction } \\
\text { Cost }(\$ / \mathrm{kW})\end{array}$ \\
\hline$A$ & $\begin{array}{l}\text { Low } \\
\text { deployment }\end{array}$ & $\begin{array}{c}\text { Low } \\
(95 / 1,695)\end{array}$ & $\begin{array}{c}\text { Low } \\
(22 \% / 40 \%)\end{array}$ & $\begin{array}{c}\text { High } \\
(\$ 5,400 / \$ 5,000)\end{array}$ \\
\hline B & $\begin{array}{l}\text { Moderate } \\
\text { deployment }\end{array}$ & $\begin{array}{c}\text { Medium } \\
(252 / 4,027)\end{array}$ & $\begin{array}{c}\text { Medium } \\
(25 \% / 62 \%)\end{array}$ & $\begin{array}{c}\text { Medium } \\
(\$ 5,000 / \$ 4,500)\end{array}$ \\
\hline C & $\begin{array}{l}\text { High } \\
\text { deployment }\end{array}$ & $\begin{array}{c}\text { High } \\
(985 / 9,760)\end{array}$ & $\begin{array}{c}\text { High } \\
(30 \% / 81 \%)\end{array}$ & $\begin{array}{c}\text { Low } \\
(\$ 5,000 / \$ 3,900)\end{array}$ \\
\hline D & $\begin{array}{l}\text { Low deploy- } \\
\text { ment with } \\
\text { more aggres- } \\
\text { sive local and } \\
\text { regional in- } \\
\text { vestment and } \\
\text { supply chain } \\
\text { development }\end{array}$ & $\begin{array}{c}\text { Low } \\
(95 / 1,695)\end{array}$ & $\begin{array}{l}\text { High } \\
\text { (30\%/81\%) }\end{array}$ & $\begin{array}{c}\text { Medium } \\
(\$ 5,000 / \$ 4,500)\end{array}$ \\
\hline$E$ & $\begin{array}{l}\text { High deploy- } \\
\text { ment with } \\
\text { less aggres- } \\
\text { sive local and } \\
\text { regional in- } \\
\text { vestment and } \\
\text { supply chain } \\
\text { development }\end{array}$ & $\begin{array}{c}\text { High } \\
(985 / 9,760)\end{array}$ & $\begin{array}{c}\text { Low } \\
(22 \% / 40 \%)\end{array}$ & $\begin{array}{c}\text { Medium } \\
(\$ 5,000 / \$ 4,500)\end{array}$ \\
\hline
\end{tabular}

How much of an economic impact a scenario will have depends most on the level of development and portion of expenditures made within the Southeast Atlantic region. In Scenario B - a moderate scenario that falls between high and low cases - development is estimated to support approximately 4,200 total jobs by 2020 and an average of nearly 12,000 jobs thereafter through 2030 . Of these, approximately $21 \%$ are estimated to be onsite, and nearly $9 \%$ are jobs manufacturing offshore wind equipment (turbines, towers, blades). Approximately 20 ongoing onsite O\&M jobs would be supported in 2020, and commissioned offshore wind projects will need approximately 330 O\&M workers by 2030. On an ongoing basis, a local supply chain would result in a greater employment impact than the installations. By 2030, approximately 4,000 ongoing local revenue and supply chain jobs are supported in this scenario. Employees with these jobs would be well compensated, with average annual earnings (including benefits) of $\$ 75,000$ for workers involved with construction and $\$ 62,000$ for O\&M workers.

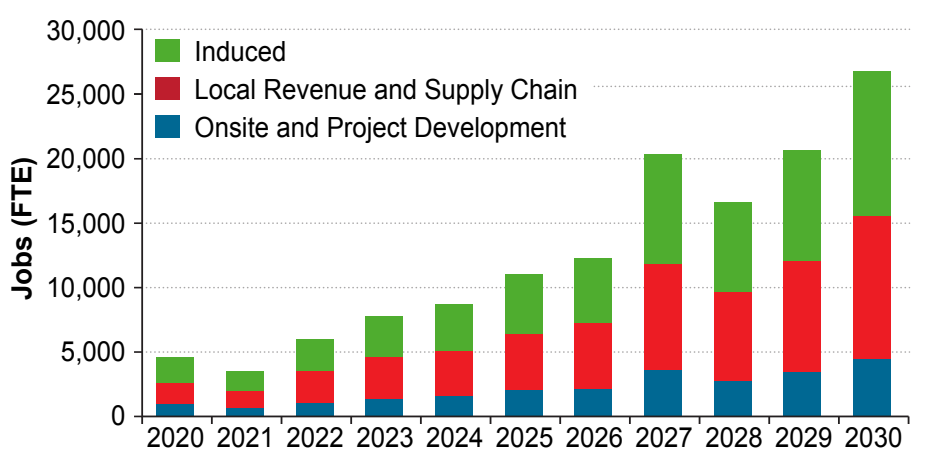

Figure 1. Estimated number of jobs supported by offshore wind deployment from 2020 to 2030.

Table 2. Jobs Supported by the Medium Scenario (Scenario B)

\begin{tabular}{|l|r|r|}
\cline { 2 - 3 } \multicolumn{1}{l|}{} & Jobs (FTE) & Jobs (FTE) \\
\hline During Construction Period & 2020 & 2030 \\
\hline $\begin{array}{l}\text { Project Development and } \\
\text { Onsite Labor Impacts }\end{array}$ & 860 & 4,150 \\
\hline $\begin{array}{l}\text { Construction and } \\
\text { Interconnection Labor }\end{array}$ & 660 & 6,760 \\
\hline Construction-related Services & 190 & 390 \\
\hline Turbine and Supply Chain Impacts & 1,550 & 7,500 \\
\hline Induced Impacts & 1,810 & 8,470 \\
\hline Total Impacts during Construction & $\mathbf{4 , 2 1 0}$ & $\mathbf{2 0 , 1 0 0}$ \\
\hline During Operating Years (Annual) & \multicolumn{2}{|c|}{} \\
\hline Onsite Labor Impacts & 20 & 330 \\
\hline Local Revenue and Supply Chain Impacts & 230 & 3,620 \\
\hline Induced Impacts & 170 & 2,760 \\
\hline Total Impacts during Operation & $\mathbf{4 1 0}$ & $\mathbf{6 , 7 0 0}$ \\
\hline
\end{tabular}

Totals may not sum due to rounding.

The U.S. DOE Wind \& Water Power Technologies Office funded James Madison University and the National Renewable Energy Laboratory to perform this work under Contract No. DE-AC36-08GO28308.

For more information on DOE offshore wind work, please visit Offshore Wind Market Acceleration Projects at www.eere.energy.gov/wind/offshore_market_acceleration.html. Renewable Energy
For more information, visit: wind.energy.gov 